\title{
Escalation of Competency Analysis of Short Stories Intrinsic Elements in Inquiry Learning by Eleventh Grade Students at SWASTA PAB 9 PATUMBAK Senior High School Academic Year 2019-2020
}

\author{
Karina Oktaviana*, Afreni, Norita, Izmawal Pebriani Nst, and Dewi Wahyuni \\ Postgraduate Universitas Muslim Nusantara Al Washliyah \\ *Corresponding author email: karinaoktaviana2910@gmail.com
}

\begin{abstract}
This study is aimed in describing inquiry learning in short story learning carried out by eleventh grade Indonesian teachers at SWASTA PAB 9 PATUMBAK Senior High School 2019/2020 academic year. The method used in this research is descriptive method. The form of this research is quantitative. Data collection techniques used in this research are observation, documentary studies, interviews, tests, and questionnaires. The data collection tools used in this study were observation guideline sheets, recording devices, interview guideline sheets, test sheets, student activity observation sheets, and questionnaire sheets. Based on the results of data analysis that has been carried out by researchers, it can be concluded that the planning and implementation of inquiry learning in short story learning in SWASTA PAB 9 PATUMBAK Senior High School is in accordance with the 2013 curriculum. The results achieved by students in inquiry learning in short story learning.
\end{abstract}

Keywords: escalation, competence, analysis

\section{INTRODUCTION}

In the 2013 curriculum, Indonesian subjects, especially at Islamic Senior High School or vocational high school eleventh grade, there is learning about literature, with Basic Competence/Kompetensi Dasar (KD): 3.3. Analyzing short story texts, both oral and written, with learning materials: Short story text analysis. And learning: Analyzing the contents of the short story text (structure, constructor, short story text linguistic rules, and short story characters).

Short stories are a form of literary work that can freely talk about the life experienced by humans with various rules and norms in their interactions with the environment so that in literary works (short stories) there is a certain meaning in life. There are several problems that arise when discussing the issue of literary works [1]-[5].

Difficulty in understanding short story content is one of the problems students often face due to a lack of knowledge about the elements contained in the short story.
Elements actually have a very close relationship with language. Knowledge of language alone is not enough to make someone understand a short story, especially the elements in a short story. Understanding the elements in the short story is important because understanding in a short story will really help readers understand the short story that is being read.

The factors that cause students' lack of understanding regarding short story learning are: (1) students are always busy/noisy during learning takes place, so that the student's concentration is not focused, (2) the presence of the teacher at the time of learning does not get the attention of students, and (3) the lack of courage of the students in asking questions. In addition, based on the results of interviews with a number of students, they admitted that there were still many difficulties in understanding short stories due to a lack of understanding of the short story building elements [6]-[8]. 
In learning activities, teachers should carry out learning effectively, this can be done by choosing the right learning method or model. The use of learning models is intended to excite students' learning. With students' passion in learning, students will not find it difficult to achieve learning goals because it is not the teacher who forces students to achieve goals, but students consciously to achieve goals. Given the importance of applying a learning model in the teaching and learning process, especially in short story learning, the teacher must apply a learning model in the teaching and learning process [9]-[13]. In addition, in accordance with the problems that occurred in PAB 9 Patumbak Senior High School, especially for students in eleventh grade. The researchers can take a conclusion that a lack of understanding of the elements of short stories causes students to have difficulty understanding the contents of the short stories. For this reason, the writer determines that the inquiry learning model is a method to improve students' understanding of short stories.

Inquiry learning model is a series of learning activities that emphasize the process of thinking critically and analytically to seek and find answers to a problem that is being questioned by Sanjaya [14]. Inquiry learning model emphasizes the process of seeking and finding answers to questions in question. Through this process of inquiry, it will generate interest in learning the subject matter and this is very important, so that students learn in conditions that are not forced [15]-[19].

Based on the above background, the researchers are interested in conducting research with the title Escalation of Competency Analysis of Short Stories Intrinsic Elements in Inquiry Learning by Eleventh Grade Students at SWASTA PAB 9 PATUMBAK Senior High School Academic Year 2019-2020.

\section{METHODOLOGY}

Research design is all the processes required in planning and conducting research. This research is in the form of classroom action research. From this name contains three words, namely as follows.

1. Research is looking at an object, using certain methodological rules to obtain data or information that is useful to improve the quality of something that is of interest and importance to researchers.

2. Action is a movement of activities that are deliberately carried out for a specific purpose, which in this study is a series of activity cycles.

3. Class is a group of students who at the same time receive the same lesson from a teacher. The written limitation for this definition of class is the old notion, to paralyze a misconception and is widely understood by the general public as "the room where the teacher teaches". Class is not a room but a group of students who are learning.

\section{RESULTS AND DISCUSSION}

To carry out this action research requires some planning. In planning this action, there are several things that need to be prepared, including:

1. the researcher and the Indonesian pamong teacher look at the subject matter in the curriculum in the implementation of the even semester where the research is conducted;

2. preparing lesson plan;

3. preparing the material to be taught;

4. arrange student observation sheets;

5. arranging tests to determine students' abilities in analyzing the intrinsic elements of the short story.

Table 1. Assessment Aspects of The Ability to Analysis of Short Stories Intrinsic Elements

\begin{tabular}{|c|c|c|c|}
\hline No & Aspect & Indicator & Score \\
\hline \multirow[t]{2}{*}{1} & Theme & If students can analyze theme precisely. & 10 \\
\hline & & If students can analyze theme incorrectly. & 5 \\
\hline \multirow[t]{2}{*}{2} & Plot & If students can analyze plot precisely. & 10 \\
\hline & & If students can analyze plot incorrectly. & 5 \\
\hline \multirow[t]{2}{*}{3} & Background & If students can analyze background precisely. & 10 \\
\hline & & If students can analyze background incorrectly. & 5 \\
\hline \multirow[t]{2}{*}{4} & Actor & If students can analyze actor precisely. & 10 \\
\hline & & If students can analyze actor incorrectly. & 5 \\
\hline \multirow[t]{2}{*}{5} & Point of view & If students can analyze point of view precisely. & 10 \\
\hline & & If students can analyze point of view incorrectly. & 5 \\
\hline \multirow[t]{2}{*}{6} & Language Style & If students can analyze language style precisely. & 10 \\
\hline & & If students can analyze language style incorrectly. & 5 \\
\hline \multirow[t]{3}{*}{7} & Mandate & If students can analyze mandate precisely. & 10 \\
\hline & & If students can analyze mandate incorrectly. & 5 \\
\hline & & TOTAL & 70 \\
\hline
\end{tabular}




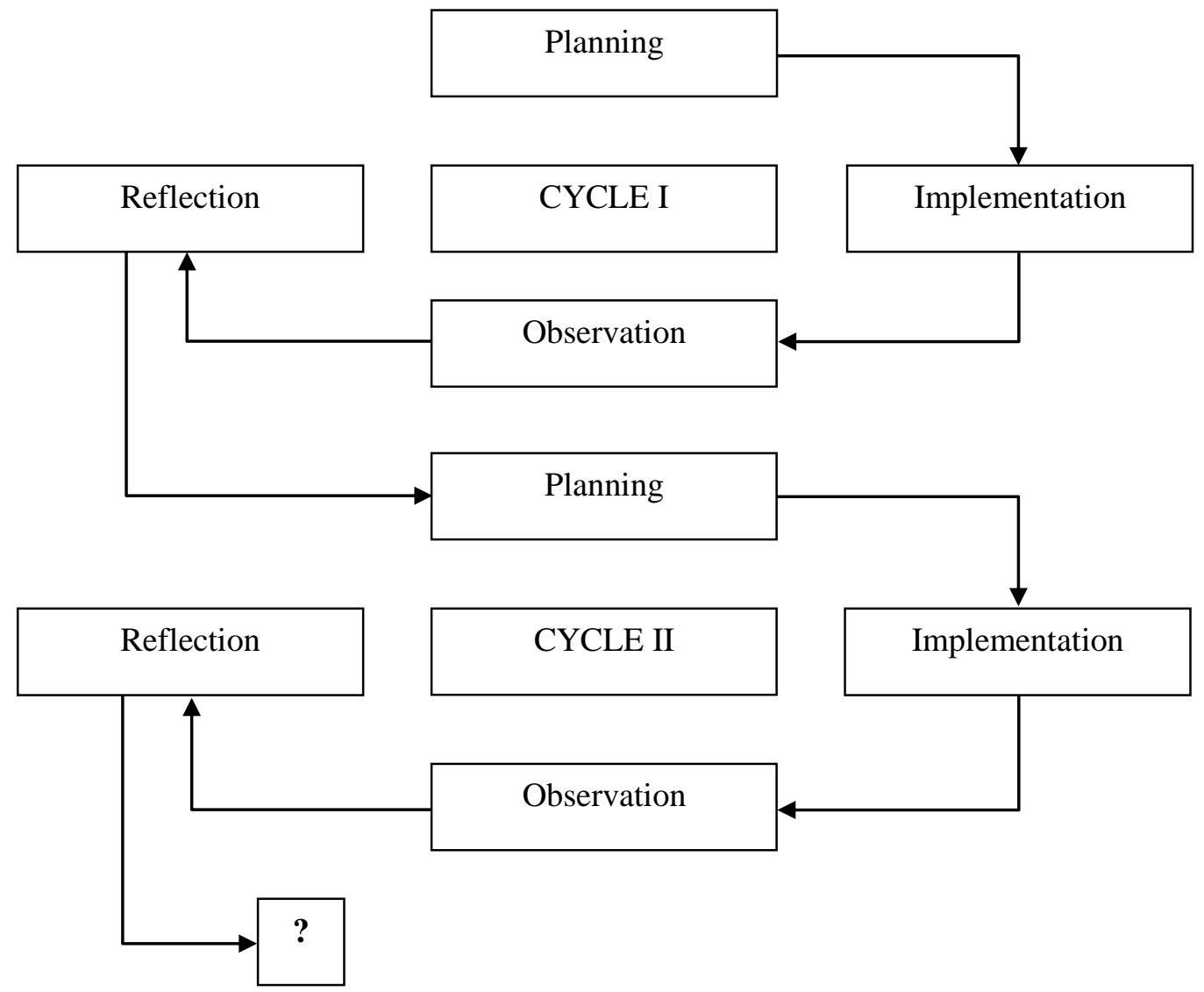

Figure 1. Action Research Cycle

Table 2. Classification of Improving the Ability to Analysis of Mirror Intrinsic Elements

\begin{tabular}{cccl}
\hline No. & Raw Score & $\begin{array}{c}\text { Standard } \\
\text { Score }\end{array}$ & \multicolumn{1}{c}{ Category } \\
\hline 1. & $62-70$ & 10 & Special \\
2. & $56-61$ & 9 & Very well \\
3. & $50-55$ & 8 & Good \\
4. & $44-49$ & 7 & More than enough \\
5. & $38-43$ & 6 & Enough \\
6. & $32-37$ & 5 & Almost enough \\
7. & $26-31$ & 4 & Less \\
8. & $20-25$ & 3 & Too less \\
9. & $14-19$ & 2 & Bad \\
10. & $8-13$ & 1 & Very bad \\
\hline
\end{tabular}

The method used to analyze the data in this research is descriptive analysis method. Descriptive analysis method is a method of data processing that is carried out by describing or describing the collected data as it is in order to obtain a general conclusion [20].

Students' ability in analyzing the intrinsic elements of short stories can be seen from learning outcomes. The test results were then analyzed in order to obtain data regarding the students 'ability to analyze the intrinsic elements, and to make it easier for researchers to analyze students' abilities, researchers used the eleven-scale absolute norm formula.

\section{CONCLUSION}

Based on observation data and student work in analyzing the intrinsic elements of the short story, the researcher reflected. This reflection can produce various possibilities. First, actions whose results are good or positive are retained and not revised. Second, actions that are still perceived as hindering or lacking need to be revised for the implementation of the next plan.

\section{REFERENCES}

[1] S. Al Alami, The Power of Short Stories, Novellas and Novels in Today's World. International Journal of Language and Literature, 4 (1) (2016), 21-35.

[2] M. P. Handayani, Using Children Short Stories to Enhance Students' Reading Comprehension. Journal of English and Education, 1 (1) (2013), 133-141.

[3] G. Tucan, What Is A Short Story Besides Short? Questioning Minds in Search of Understanding Short 
Fiction. Romanian Journal of English Studies, 11 (1) (2014), 1-8.

[4] A. E. Frimasary, Using Short Story to Improve Student's Reading Comprehension (A Study at the Second Year Student of SMPN 2 Kota Bengkulu). Journal of Linguistics and Language Teaching, 2 (2) (2015), 8 pages.

[5] Hasbaini, A. Manan, Teaching Reading Comprehension by Using Short Stories. English Education Journal, 8 (3) (2017), 404-423.

[6] H. Ayuningsih, I. Zulaeha, The Effectiveness of Learning Using Short Story Writing Multiliteracy Model with Public Service Advertising Media Based on The Learning Types of Senior High School Students. Seloka: Jurnal Pendidikan Bahasa dan Sastra Indonesia, 8 (3) (2019), 70-77.

[7] A. Sultan, J. Nafi, Z. Qabaja, S. Al-Abed, The Effect of Using Short Stories on The Development Of 5th Graders' Reading Comprehension Skills in Hebron District. International Journal of English Language Teaching, 5 (4) (2018), 1-27.

[8] N. O. Ceylan, Using Short Stories in Reading Skills Class. Procedia - Social and Behavioral Sciences, 232 (2016), 311-315.

[9] S. Mahanal, S. Zubaidah, I. D. Sumiati, T. M. Sari, N. Ismirawati, RICOSRE: A Learning Model to Develop Critical Thinking Skills for Students with Different Academic Abilities. International Journal of Instruction, 12 (2) (2019), 417-434.

[10] Fajriah, Learning Journal: Improving Teaching Strategies Through Students' Reflections. Sukma: Jurnal Pendidikan, 1 (2) (2017), 301-327.

[11] S. B. Eom, A System's View of E-Learning Success Model. Decision Sciences Journal of Innovative Education, 16 (1) (2018), 42-76.

[12] T. M. Sari, S. Mahanal, S. Zubaidah, Empowering Critical Thinking with Ricosre Learning Model. Jurnal Pendidikan Sains, 6 (1) (2018), 1-5.

[13] Y. M. Azis, H. Suharyati, S. Susanti, Student's Experience of E-Learning, Learning Process and Perceived Learning Outcomes in Economic Math Course. Journal of Humanities and Social Studies, 3 (2) (2019), 67-71.

[14] W. Sanjaya, Strategi Pembelajaran Berorientasi Standar Proses Pendidikan. Jakarta: Kencana, 2009.
[15] M. Jannah, Z. A. I. Supardi, Prabowo, Guided Inquiry Model with the REACT Strategy Learning Materials to Improve the Students' Learning Achievement. IJORER: International Journal of Recent Educational Research, 1 (2) (2020), 156-168.

[16] R. P. Gumilar, S. Wardani, L. Lisdiana, The Implementation of Guided Inquiry Learning Models on The Concept Mastery, Scientific Attitude, and Science Process Skill. Journal of Primary Education, 8 (5) (2019), 148-154.

[17] B. K. Khalaf, Z. Bt. M. Zin, Traditional and Inquiry-Based Learning Pedagogy: A Systematic Critical Review. International Journal of Instruction, 11 (4) (2018), 545-564

[18] S. Mulyani, Rusdi, D. Vivanti, The Effect of Guided Inquiry Learning Model and Scientific Performance on Student Learning Outcomes. Indonesian Journal of Science and Education, 2 (1) (2018), 105-109.

[19] I. M. A. Wirawan, I. M. G. Sunarya, I. G. N. T. Jayendra, A. Yudianto, Mobile Learning Based-On Guided Inquiry: Optimization of Students' Motivation. Jurnal Pendidikan Teknologi dan Kejuruan, 24 (2) (2018), 256-261.

[20] Sugiyono, Metode Penelitian Tindakan. Bandung: Alfa Beta, 2008. 